\title{
In vitro androgenesis in pepper and the affecting factors on success: I. Carbon source and concentrations
}

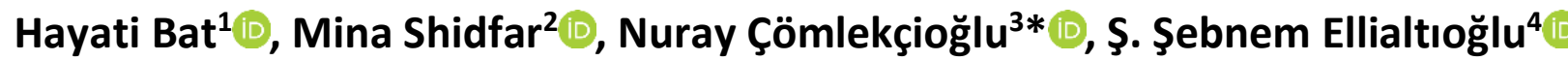 \\ ${ }^{1}$ United Genetics Turkey Vegetable Seeds Company, 34788 Cekmekoy, Istanbul, Turkey. \\ ${ }^{2}$ R\&D Tissue Culture Laboratory, United Genetics Turkey, 16500 Mustafakemalpasa, Bursa, Turkey. \\ ${ }^{3}$ Department of Horticulture, Faculty of Agriculture, Eskisehir Osmangazi University, 26160 Odunpazari, Eskisehir, \\ Turkey. \\ ${ }^{4}$ Department of Horticulture, Faculty of Agriculture, Ankara University, 06110 Diskapi, Ankara, Turkey.
}

\section{Article History}

Received 08 October 2020

Accepted 22 November 2020

First Online 27 November 2020

\section{* Corresponding Author}

Tel.: +90 2223242990

E-mail: ncomlekcioglu@ogu.edu.tr

\section{Keywords}

Anther culture

Capsicum annuum L.

Haploid

Maltose

Sucrose

\begin{abstract}
In vitro androgenesis methods are significant in rapid production of completely homozygous lines. Factors such as nutrient medium composition, types and concentrations of carbohydrate sources are effective on androgenetic success. Different sugar types were tested at different doses in anther culture of pepper to elucidate their influence on the yield of androgenesis. In this study, maltose was used as a source of sugar at $1.5,3$ and $6 \%$ doses. $3 \%$ sucrose was used as the control treatment. Murashige \& Skoog (1962-MS) medium and $0.25 \%$ activated charcoal, 15 $\mathrm{mg} \mathrm{L}^{-1}$ silver nitrate $\left(\mathrm{AgNO}_{3}\right), 4 \mathrm{mg} \mathrm{L^{-1 }}$ naphthaleneacetic acid (NAA), and 2 different amounts of 6-benzylaminopurine $\left(0.5,1 \mathrm{mg} \mathrm{L}^{-1} \mathrm{BAP}\right)$ with three breeding lines of pepper were used to know the genotypic effects on haploid embryo formation. When comparing 1.5, 3 and $6 \%$ maltose and $3 \%$ sucrose with each other in the medium, embryo response increased with maltose concentration. Maltose, which was generally compare to sucrose as carbohydrate source for anther culture, the embryo response had significantly affected at maltose concentrations. The combination with the best effect among the trial parameters was $30 \mathrm{~g} \mathrm{~L}^{-1}$ maltose and $0.5 \mathrm{mg} \mathrm{L}^{-1} \mathrm{BAP}$ for obtaining embryos from anther culture. Also, it was found that genotype is one of the main factors affecting success in pepper anther and microspore culture.
\end{abstract}

\section{Introduction}

Pepper which belongs to the Capsicum genus and Solanaceae family is a domesticated species originated from the tropical and sub-tropical central regions of South America known as Bolivia (Olmstead et al., 2008). All pepper populations are diploid and have the same chromosome number $(2 n=2 x=24)$. Capsicum annuum $\mathrm{L}$. is widely grown and produced all over the world. It was domesticated from wild bird pepper or 'Chiltepin' in Mexico (Perry et al., 2007; Yildiz et al., 2020). However, it is the most broadly distributed and economically crop of the world. Red pepper cv. Capia (C. annuum) type is an essential and widely used among other vegetables all over the world. Turkey, due to its geographical location and soil fertility has played an important role in the distribution of different plant species. It is one of the most important country having great cultivation of peppers. Annual production and harvested area of dry peppers and green peppers in Turkey were reported to be 16,355 tones and 6,749 ha and 2,608,172 tones and 94,444 ha, respectively (FAOSTAT, 2017).

One of the most important and original aims of the breeding programs in capia type pepper is development of new marketable cultivars. The most commonly used method by pepper breeders is pure line and pedigree selection. Biotechnological methods such as doubled haploid (DH) plant production, are intended for reducing the breeding process of these new homogenous and totally pure varieties (Lantos et al., 2012; Thomas et al., 2003). Obtaining high quality homozygous pure lines by classical methods is very time consuming (nearly 6-7 
years) and labor intensive. Time can be shortened up to 1 year using androgenesis to obtain haploid plants via tissue culture. Microspore embryogenesis is an important and useful culture technique to obtain full homozygous lines from only the male gametes in pepper breeding (Comlekcioglu \& Ellialtioglu, 2018). The first successful haploid embryo development from $C$. annuum anthers was happened by Wang et al. (1973) in China, George, and Narayanaswamy (1973) in India. In Turkey, the first in vitro androgenesis studies on domestic pepper genotypes were started by Abak (1983). Afterwards, many scientists in different parts of the world have investigated the factors affecting anther culture and published their valuable experiences. Some of the essential factors such as growing condition of donor plants, collection of donor buds in the optimal stage (Ari et al., 2016 a,b; Kim et al., 2004; Supena et al., 2006), pre-treatments of buds or anthers (Dumas de Vaulx et al., 1981), nutrient media (Comlekcioglu et. al., 2001; Dumas de Vaulx et al., 1981; Dumas de Vaulx, 1990; Irikova et al., 2011; Ozkum-Ciner \& Tipirdamaz, 2002; Qin \& Rotino, 1993; Supena et al., 2006), temperature treatment (Dolcet-Sanjuan et al., 1997; Koleva-Gudeva et al., 2009), culture season (Buyukalaca et al., 2004; Ercan et al., 2006; Gonzalez-Garcia, 2002; Rodeva \& Cholakov, 2006; Taskin et al., 2011), incubation conditions (Ellialtioglu et al., 2001), plant growth regulators and genotype of the donor plant (Ari et al., 2016a,b; Buyukalaca et al., 2004; Comlekcioglu et. al., 2001; Wang \& Zhang, 2001) which significantly influence the usefulness of haploidy could affect androgenetic responses.

Among the various factors used to increase the rate of haploid plants and cross-species hybrids of $C$. annuum, carbohydrate sources as nutrient components play a very important role. Many researchers have reached substantial results by changing source and concentration of carbohydrates (sucrose, maltose, and glucose) in the nutrient medium, in order to increase the effectiveness of microspore embryogenesis. Sucrose at different concentrations is commonly used as a carbohydrate source for in vitro cultivation of pepper anthers by Binzel et al. (1996), Morrison et al. (1986), and Supena et al. (2006). Maltose also used by DolcetSanjuan et al. (1997), Gémesné et al. (2000), and Supena et al. (2006). There are very few research about using honey as a carbohydrate source instead of sucrose. Gebologlu et al. (2017) stated that the use of honey contributes positively to embryo formation, but this effect varies depending on genotypes. Consequently, different experiments are carrying out to create new protocols for effective embryo production in pepper.

In order to be used as parents in F1 hybrid variety breeding, 3 genotypes of sweet capia type pepper were studied to developed pure lines. The main propose of this work was to investigate the effect of different concentrations of maltose and sucrose as a carbohydrate sources in anther culture.

\section{Materials and Methods}

This research was carried out in the Tissue culture Laboratory owned by United Genetics Seed. A.S Company in Bursa, Turkey.

\section{Plant material}

In the current study, three different breeding lines (G-23, G-24, and G-26) of capia type peppers were used as a plant material. Pepper seeds were planted in styrofoam containing peat: perlite with the ratio of 2:1 in the greenhouse conditions, of the United Genetics Turkey Vegetable Seeds Company at Mustafakemalpaşa/Bursa location. Seedlings (42 dayold) were transferred into a controlled greenhouse to be grown as donor plants (Figure 1a). Due to the importance of healthy growth and development conditions of the donor plant, they were subjected to growth free from any stress like insects, weeds, diseases, water and nutrient deficiencies (Figure 1b).

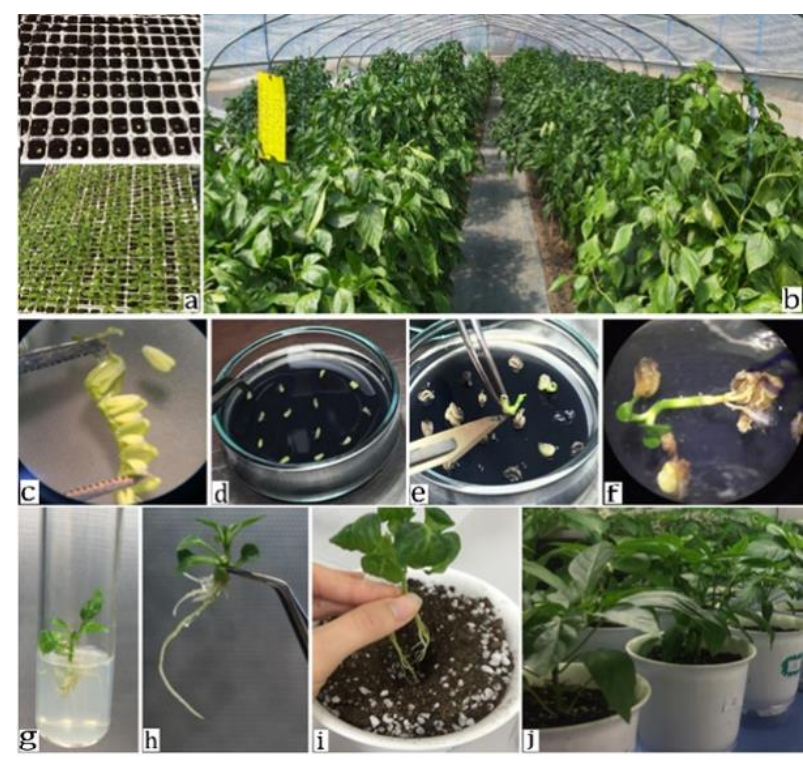

Figure 1. (a) Planting donor plants seeds and growing the seedlings, (b) donor plants in the controlled greenhouse, (c) isolation of anthers from buds under aseptic conditions, (d) putting the anthers into the petri dishes, (e) transferring the embryos to hormone-free MS medium, (f) haploid plantlet under stereomicroscope, (g) growing of embryos in vitro, (h) removing advanced embryos from the test-tube, (i) acclimatization of pepper plantlets, (j) healthy androgenic pepper plants.

\section{Anther culture studies}

Flower buds were collected in the morning. In the phase when the corolla and the calix are at the same height or when the the height of corolla is a little above the height of the calix and also when there is an anthocyanin production, mostly late uninucleate and mid uninucleate microspore stage were found alongside anthers that contain pollen in the young binucleate stage (Comlekcioglu \& Ellialtioglu, 2018).

Surface sterilization and anther extraction is also critical in anther culture. In the laboratory this method 
started with washing flower buds with sterile distilled water very quickly. Then $70 \%$ ethanol sprayed on buds and kept in $2.5 \%$ sodium hypochlorite and a drop of Tween-20 for 10 minutes and washed in sterile distilled water 3 times or more to remove the traces of sodium hypochlorite. And later all buds are carefully cut (Figure 1c) and examined with using a microscope inside laminar flow cabinet (anther should not be damaged during cutting) on a sterile paper and cultured horizontally on the pepper agar medium (Figure 1d).

\section{Treatments and observations}

Anthers of three capia (G-23, G-24, and G-26) pepper genotypes (breeding lines) were cultured on MS (Murashige \& Skoog, 1962) media including vitamins and plant growth regulators. It was previously reported (Buyukalaca et al., 2004; Keles et al., 2015 and Taskin et al., 2011) that MS nutrient media supplemented with NAA, BAP, activated charcoal, sucrose and $\mathrm{AgNO}_{3}$ were successful in the androgenesis of pepper. Actually, 8 different types of culture media were prepared supplemented with $4 \mathrm{mg} \mathrm{L}^{-1} \mathrm{NAA}, 15 \mathrm{mg} \mathrm{L}^{-1} \mathrm{AgNO}_{3}$, $0.25 \%$ activated charcoal, and $8 \mathrm{~g} \mathrm{~L}^{-1}$ agar for all under the same condition. Variable factors were BAP with (0.5, $1 \mathrm{mg} \mathrm{L}^{-1}$ ) doses and carbon source and concentrations as maltose with 15,30 and $60 \mathrm{~g} \mathrm{~L}^{-1}$ and sucrose $30 \mathrm{~g} \mathrm{~L}^{-1}$ as a control treatment.

The cultures were incubated in the dark conditions for 2 days at $35^{\circ} \mathrm{C}$, later at $25^{\circ} \mathrm{C}$ for 4 to 6 weeks to induce direct embryogenesis continuously. Embryo formation (Figure 1e and 1f), development, germination and transformation into a complete plantlet were regularly observed. After growing embryos were transferred to
MS medium without any plant growth regulator (Figure $1 \mathrm{~g}$ ) and were kept in light with 16 hours photoperiod at $25^{\circ} \mathrm{C}$. After few days the embryos were transferred into sterile coco peat pots (Figure $1 \mathrm{~h}$ and $1 \mathrm{i}$ ) for shoot and root elongation (Figure 1j).

\section{Experiment design and statistical analyses}

The experiment was carried out in a "completely randomized design" with four replications and 5 petri dishes per repetition. Five anthers obtained from a flower bud were planted in each petri dishes (20 Petri dishes and 100 anthers were used in each medium). Data were subjected to analysis of variance (ANOVA, Tarist Statistical Software) and means were separated by LSD test (A probability level $P<0.01$ was used to test significance of differences between means).

\section{Results and Discussion}

In this study, for evaluating of embryo induction of anthers of three Capia pepper genotypes (G-23, G-24, and G-26) were cultured on MS medium including $(0.5$ and $\left.1.0 \mathrm{mg} \mathrm{L}^{-1}\right)$ BAP with different concentrations of maltose $\left(15,30\right.$ and $\left.60 \mathrm{~g} \mathrm{~L}^{-1}\right)$ and sucrose $\left(30 \mathrm{~g} \mathrm{~L}^{-1}\right)$ as a carbon source.

The data presented in Table 1 show the effect of different carbon sources and BAP doses on number of embryos per 100 anther obtained and developed embryos obtained on pepper anther culture. According to data, G-26 genotype produced significantly higher embryos at each carbon and BAP level than the other two genotypes. This technology consists of stimulation and germination of haploid plants via anther or

Table 1. Number of embryos from different carbon sources, doses and two different doses of BAP in the culture medium

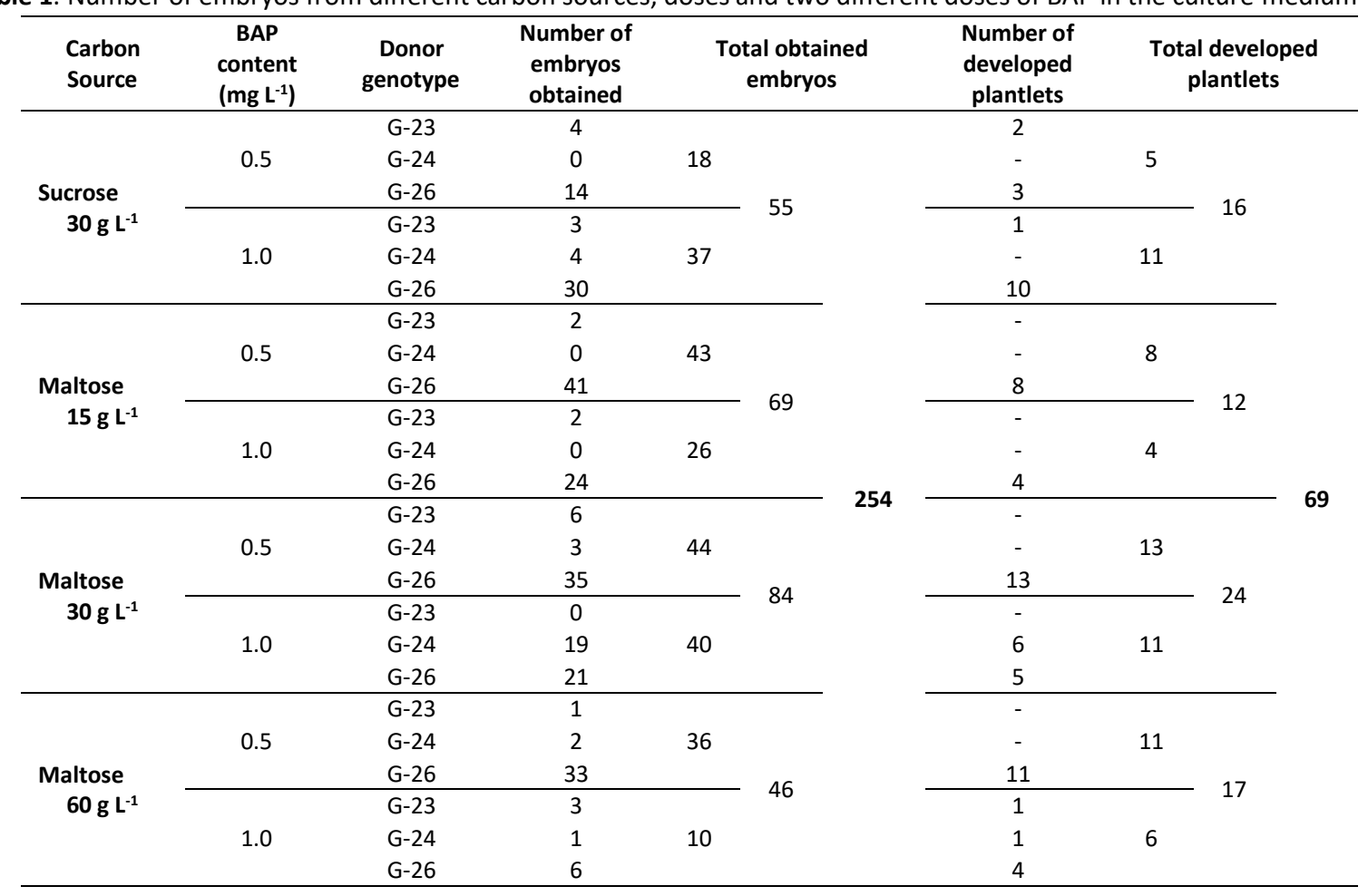


Ari, E., Bedir, H., Yildirim, S., \& Yildirim, T. (2016a). Androgenic responses of 64 ornamental pepper (Capsicum annuum L.) genotypes to shed-microspore culture in the autumn season. Turk Journal of Biology, 40, 706-717.

Ari E., Yildirim T., Mutlu N., Buyukalaca S., Gokmen U., \& Akman E. (2016b). Comparison of different androgenesis protocols for doubled haploid plant production in ornamental pepper (Capsicum annuum L.). Turkish Journal of Biology, 40, 944-954.

Binzel, M. L., Sankhla, N., Joshi, S., Sankhla, D. (1996). Induction of direct somatic embryogenesis and plant regeneration in pepper (Capsicum annuum L.). Plant Cell Rep., 15, 536-540.

Buyukalaca, S., Comlekcioglu, N., Abak, K., Ekbic, E., Kilic., N. (2004). Effect of silver nitrate and donor plant growing conditions on production of pepper (Capsicum annuum L.) haploid embryos via anther culture. Europ. J. Hort. Sci., 69(5), 206-209.

Comlekcioglu, N., Buyukalaca, S., \& Abak, K. (2001). Effect of silver nitrate on haploid embryo induction by anther culture in pepper (Capsicum annuum L.). In: XIth EUCARPIA Meeting on Genetics and Breeding of Capsicum and Eggplant, Antalya, Turkey, pp 133-136.

Comlekcioglu, N., \& Ellialtioglu, S. (2018). Review on the research carried out on in vitro androgenesis of peppers (Capsicum annuum L.) in Turkey. Research Journal of Biotechnology, 13(6), 75-84.

Dolcet-Sanjuan, R., Claveira, E., \& Huerta, A. (1997). Androgenesis in Capsicum annuum L. Effects of carbohydrate and carbon dioxide enrichment. J Amer Soc Hort Sci., 122, 468-475.

Dumas de Vaulx, R. (1990). Haploid and pepper breeding: A review. Capsicum Newsletter, 8-9, 13-17.

Dumas de Vaulx, R., Chambonnet, D., \& Pochard, E. (1981). In vitro anther culture in red pepper (Capsicum annuum L.): Improvement of the rate of plant production in different genotypes by treatments at $+35^{\circ} \mathrm{C}$. Agronomie, 1 , 859864.

Ellialtioglu, S., Kaplan, E., \& Abak, K. (2001). The effect of carrot extract and activated charcoal on the androgenesis of pepper. In: XIth EUCARPIA Meeting on Genetics and Breeding of Capsicum and Eggplant, Antalya, Turkey, pp 142-145.

Ercan, N., Sensoy, F. A., \& Sensoy, A. S. (2006). Influence of growing season and donor plant age on anther culture response of some pepper cultivars (Capsicum annuum L.). Sci Hort., 110, 16-20.

FAOSTAT, (2017). fao.org/faost at/en/\#data/QC.

Gebologlu, N., Toksoz, S., Durna, P., \& Bayram, M. (2017). Patlıcanda şeker, bal ve büyüme düzenleyicilerin anter kültüründe embriyoid oluşumuna etkisi. Akademik Ziraat Dergisi, 6(Özel sayı), 275-280.

Gémesné, J.A., Gyulai, G., Petus, M., Venczel, G., Sagi, Z., Zatyko, L. (2000). DH-Breeding of sweet pepper (Capsicum annuum L.). Biotechnological Approaches for Utilization of Gametic Cells COST 824 Final Meeting, Bled, Slovenia, pp 157-159.

George, L., \& Narayanaswamy, S. (1973). Haploid Capsicum through experimental androgenesis. Protoplasma, 78, 467-480.

Germana, M. A. (2011). Anther culture for haploid and doubled haploid production. Plant Cell, Tissue and Organ Culture, 104(3), 283-300.

Gonzalez-Garcia, J. (2002). Plant induction by anther culture of jalapeno pepper (Capsicum annuum L.). Yeast Genetics and Molecular Biology, University of Wisconsin, Madison, USA, July 30-August.

Irikova, T., Grozeva, S., \& Rodeva, V. (2011). Anther culture in pepper (Capsicum annuum L.) in vitro. Acta Physiol Plant., 33, 1559-1570.

Keles, D., Pinar, H., Ata, A., Taskin, H., Yildiz, S., \& Buyukalaca, S. (2015). Effect of pepper types on obtaining spontaneous doubled haploid plants via anther culture. HortScience, 50(11), 1671-1676.

Kim M., Kim J., Yoon M., Choi D. I., \& Lee K. M. (2004). Origin of multicellular pollen and pollen embryos in culturedanthers of pepper (Capsicum annuum) Plant Cell, Tissue and Organ Culture 77, 63-72.

Koleva-Gudeva, L., Spasenoski, M., \& Trajkova F. (2007). Somatic embryogenesis in pepper anther culture: The effect of incubation treatments and different media. Scientia Horticulturae, 111, 114-119.

Koleva-Gudeva, L., Trajkova, F., Dimeska, G., Spasenoski, M. (2009). Androgenesis efficiency in anther culture of pepper (Capsicum annuum L.). Acta Horticulturae, 830, 183-190.

Lantos, C., Juhasz, A. G., Vagi, P., Mihaly, R., Kristof, Z., Pauk, J. (2012). Androgenesis induction in microspore culture of sweet pepper (Capsicum annuum L.). Plant Biotechnology Rep, 6, 123-132.

Morrison, R. A., Koning, E. R., \& Evans, D. A. (1986). Anther culture of an interspecific hybrid of Capsicum. Journal of Plant Physiology, 126, 1-9.

Murashige, T., \& Skoog, F. (1962). A revised medium for rapid growth and bioassays with tobacco tissue cultures. Physiol Plant., 15, 473-497.

Olmstead, R. G., Bohs, L., Migid, H. A., Santiago-Valentin, E., Garcia, V., \& Collier, S. M. (2008). Molecular phylogeny of the Solanaceae. Taxon, 57, 1159-1181.

Ozkum-Ciner, D., \& Tipirdamaz, R. (2002). The effects of cold treatment and charcoal on the in vitro androgenesis of pepper (Capsicum annuum L.). Turk Journal of Botany, 26, 131-139.

Ozkum-Ciner, D. \& Tipirdamaz, R. (2011). Effects of I-proline and cold treatment on pepper (Capsicum annuum L.) anther culture, In Gökçekus S. et al, eds., Survival and Sustainability, Environmental Earth Sciences, Springer, Berlin, 137-143.

Perry, L., Dickau, R., Zarrillo, S., Holst, I., Pearsall, D. M., Piperno, D. R., Berman, M. J., Cooke, R. G., Rademaker, K., Ranere, A. J., Raymond, J. S. (2007). Starch fossils and the domestication and dispersal of chili peppers (Capsicum spp. L.) in the America. Science, 315, 986-988.

Qin, X., \& Rotino, G. L. (1993). Anther culture of several sweet and hot pepper genotypes. Capsicum \& Eggplant News, $12,59-62$.

Rodeva, V., \& Cholakov, T. (2006). Influence of some climatic factors in the period of donor plants growing on responsiveness of pepper anthers to embryogenesis. In: The International Conference Haploids in Higher Plants III, Vienna, Austria, p 42.

Rodeva, V., Irikova, T., \& Todorova, V. (2004). Anther culture of pepper (Capsicum annuum L.): Comparative study on effect of the genotype. Biotechnol \& Biotechnol Equip., 3, 34-38.

Segui-Simarro, J. M., Corral-Martinez, P., Parra Vega, V., Gonzalez-Garcia, B. (2011). Androgenesis in recalcitrant Solanaceous crops. Plant Cell Report, 30, 765-778.

Supena, E. D., Suharsono, S., Jacobsen, E., Custers, J. B. (2006). Successful development of a shed-microspore culture 
protocol for doubled haploid production in indonesian hot pepper (Capsicum annuum L.). Plant Cell Reports, 25, 1-10.

Taskin, H., Buyukalaca, S., Keles, D. Ekbic, E. (2011). Induction of Microspore-Derived Embryos by Anther Culture in Selected Pepper Genotypes. African Journal of Biotechnology, 10,17116-17121.

Thomas, W. T. B., Forster, B., \& Gertsson, B. (2003). Doubled haploids in breeding. In: Maluszynski $M$, Kasha KJ, Forster BP, Szarejko I (eds) Doubled Haploid Production in Crop Plants. Kluwer Academic Publishers, Dordrecht, pp. 337-349.
Wang, Y. Y., Sun, C. S., Wang, C. C., Chien, N. J. (1973). The induction of pollen plantlets of triticale and Capsicum annuum anther culture. Sci Sin., 16, 147-151.

Wang, L. H., \& Zhang, B. X. (2001). Advancement in the Anther Culture of Capsicum annuum L. China Veg., 3, 52-53.

Yildiz, M., Kocak, M., Nadeem, M.A., Cavagnaro, P., Barboza, K., Baloch, F. S., Argun, D., Keles, D. (2020). Genetic diversity analysis in the Turkish pepper germplasm using iPBS retrotransposon-based markers. Turk Journal of Agriculture and Forestry, 44, 1-14. 